\title{
Erratum
}

\section{$\beta$-Adrenoceptor changes in human lymphocytes, induced by dynamic exercise}

\section{O.-E. Brodde, A. Daul, and N. O'Hara}

Biochemisches Forschungslaboratorium, Medizinische Klinik und Poliklinik, Abteilung für Nieren- und Hochdruckkranke, Huflandstrasse 55, 4300 Essen

Naunyn-Schmiedeberg's Arch Pharmacol 325:190 - 192 (1984)

Due to a calculation error, the following numbers must be changed:

\section{Results section}

line 3: $926 \pm 72$ specific ICYP binding sites/cell instead of $463 \pm 36$

line 9: $1440 \pm 128$ specific ICYP binding sites/cell instead of $720 \pm 64$

line 17: $8.1 \pm 1.2$ pmoles $/ 10^{6}$ cells instead of $3.2 \pm 0.4$

line 19: $13.4 \pm 1.8$ pmoles $/ 10^{6}$ cells instead of $5.3 \pm 0.5$

line $25: 5.6 \pm 0.9$ pmoles $/ 10^{6}$ cells instead of $2.4 \pm 0.3$

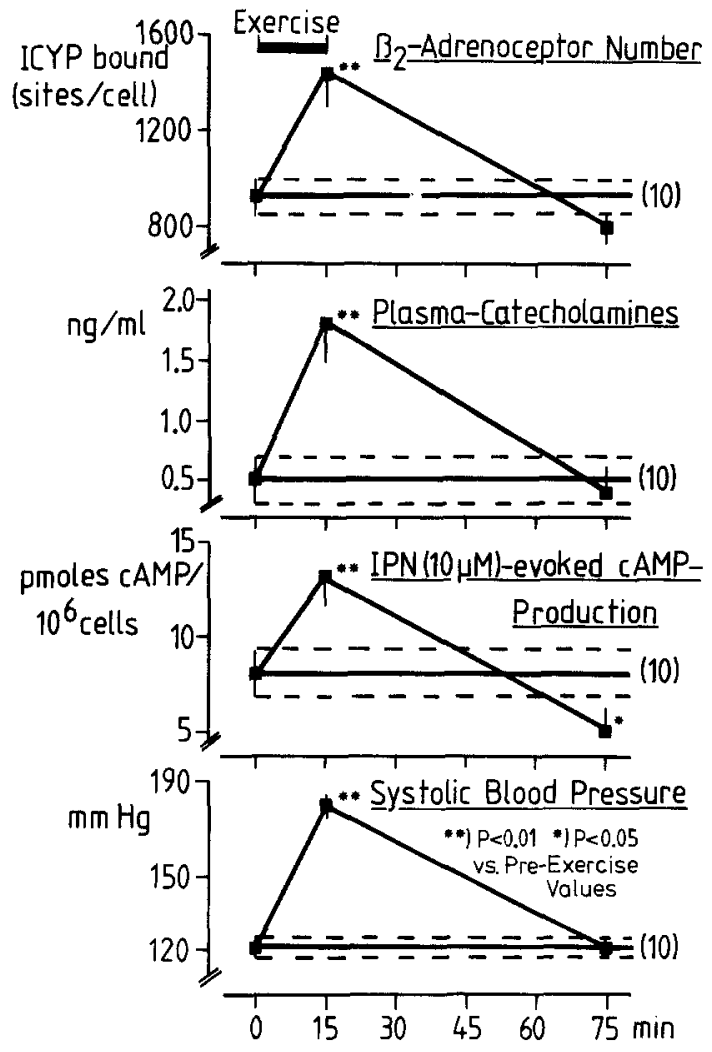

Fig. 1. Ordinates for $\beta_{2}$-adrenoceptor number and for cyclic AMP production evoked by $10 \mu \mathrm{mol} / 1$ isoprenaline 